\title{
Induced pluripotent stem cell technology for disease modeling and drug screening with emphasis on lysosomal storage diseases
}

\author{
Hsiang-Po Huang1, Ching-Yu Chuang² and Hung-Chih Kuo ${ }^{* 2,3}$
}

\begin{abstract}
The recent derivation of disease-specific induced pluripotent stem cells (iPSCs) from somatic cells of patients with familial and sporadic forms of diseases and the demonstration of their ability to give rise to disease-relevant cell types provide an excellent opportunity to gain further insights into the mechanisms responsible for the pathophysiology of these diseases and develop novel therapeutic drugs. Here, we review the recent advances in iPSC technology for modeling of various lysosomal storage diseases (LSDs) and discuss possible strategies through which LSD-iPSCs can be exploited to identify novel drugs and improve future clinical treatment of LSDs.
\end{abstract}

\section{Introduction}

By using a combination of transcription factors that had previously yielded success in reprogramming mouse somatic cells [1], Yamanaka and colleagues demonstrated that human somatic cells can be directly reprogrammed to a pluripotent state similar to that of their embryonic stem cell (ESC) counterparts in vitro [2]. The human induced pluripotent stem cells (iPSCs) created by the reprogramming process exhibit the typical characteristics of human ESCs, showing morphology and growth requirements and surface and pluripotent-related marker expression similar to those of their inner cell massderived counterparts [2-4]. Furthermore, both in vitro differentiation and in vivo teratoma formation analyses indicate that human iPSCs are truly PSCs as they are able to give rise to cell types representing all three embryonic germ layers $[2,5]$.

\footnotetext{
*Correspondence: kuohuch@gate.sinica.edu.tw
}

${ }^{2}$ Genomics Research Center, Academia Sinica, No. 128, Sec. 2, Academia Road, Nankang, Taipei 115, Taiwan

Full list of author information is available at the end of the article
Lysosomal storage diseases (LSDs) are individually rare but collectively common; their estimated total prevalence is 1 out of 8,000 live births [6]. As current therapies have limited effect and most LSDs progress relentlessly, therapies that are more efficient are urgently needed. To develop efficient therapies, a more thorough understanding of the pathophysiological development of LSDs at the cellular level is essential. Several LSD disease models have been established in knockout mice for disease modeling and drug tests [7-12]. However, at present, these models are not able to mimic the whole spectrum of LSD conditions. Therefore, lack of appropriate human cells affected by LSDs for drug screening and toxicity testing may be a major obstacle in the development of new therapies for LSDs. Since pluripotency reprogramming technology offers an easy and efficient means to generate patient-specific iPSCs, the iPSCs derived from patients with familiar or sporatic disease offer a valuable methodology through which to study the mechanisms involved in the initiation and progression of LSDs in vitro and further screen remedies for clinical treatment.

This review focuses on the current status of the application of iPSCs in LSD research by summarizing the LSD-iPSC cellular/ultrastructural findings that have been reported in the literature and by presenting useful strategies for drug designing/screening using LSD-iPSCs. We hope this review will encourage additional translational research in LSD drug development using this novel stem cell technology.

\section{Lysosomal storage diseases}

Lysosomes are unique intracellular organelles that contain an array of enzymes that are responsible for degrading aged organelles and disused macromolecules, such as glycoproteins, glycosaminoglycans (GAGs), and glycolipids. Lysosomes are involved in many important cellular functions, including autophagy, exocytosis, receptor recycling, phagocytosis, and membrane trafficking $[13,14]$. LSDs are a large and heterogeneous group of genetic disorders caused mainly by deficiencies in different kinds of lysosomal enzymes, which result in various 
organelle dysfunctions relating to the accumulation of specific substrates (Table 1) [14]. LSDs also encompass two other types of rare disorders caused by either transport defects through the lysosomal membrane $[14,15]$ or defective vesicular trafficking (Table 1) [14,16,17]. The majority of LSDs are clinically progressive and currently have no definite cures. Recent development of enzyme replacement therapy (ERT) has successfully alleviated the symptoms of patients with certain types of LSDs, such as Gaucher's disease, Pompe disease, Fabry disease, and type I, II, and VI mucopolysaccharidosis (MPS) [18], but the benefit of ERT on the neurological manifestations of LSDs is less obvious [19]. Hematopoietic stem cell transplantation [20], substrate reduction therapy [21], and pharmaceutical chaperones [22] have also been developed to treat selected patients with LSDs and showed beneficial effects [23]. Nevertheless, for patients with advanced-stage or late-onset LSDs, the current treatment results are still not satisfactory.

\section{History and progress of induced pluripotent stem cell technology}

In 2006, Yamanaka and colleagues [1,2] demonstrated that forced expression of only four transcription factors (Oct3/4, Sox2, Klf4, and c-Myc) is sufficient to convert both mouse and human fibroblasts into ESC-like cells. Other researchers reported similar results at almost the same time [24-26]. The cells generated were named iPSCs. Such a breakthrough circumvented the thorny ethical issues surrounding research that employs human embryos and also offered the hope of providing replaceable human cells with less immune rejection for use in clinical applications. A major disadvantage of iPSC technology is its low efficiency. However, an increasing number of modified protocols employing chemicals and small molecules have been forwarded to improve the efficiency of iPSC derivation; these methods have been reviewed extensively elsewhere [27-29]. In addition, alternative strategies have been developed to avoid the problem of integration of viral genes, including piggyBac vectors [30], recombinant proteins [31], modified mRNAs [32], microRNAs [33], and Sendai virus [34]. In general, however, it is accepted that the most efficient method to generate human iPSCs is still through lentiviral and retroviral transduction [35]. While iPSC research in vitro has progressed considerably, the large-scale application of iPSCs in clinical practice in the near future still hangs in the balance, mainly because of the concern of tumorigenicity that is comparable to that of ESCs. In addition, a recent report [36] demonstrated that the teratomas from inbred C57BL/6 fibroblast-derived iPSCs still cannot prevent the occurrence of immune rejection when transplanted back to the syngeneic mice, although Okita and colleagues [37] argued against this conclusion and reasoned that teratoma formation might not be a good approach through which to evaluate immune rejection. Consistent with this viewpoint, transplantations of mutation-corrected iPSC-derived cells into affected mice have been shown to result in the rescue of disease phenotypes in mice with sickle cell anemia [38]. Nevertheless, it should be borne in mind that de novo immunogenicity might be produced during iPSC derivation and maintenance, which could be caused by, for example, the viral antigens generated by viral vectors or the animal antigens contained in the serum or supplements used for cell culture. Despite all of these uncertainties regarding clinical application, it is well recognized that human iPSCs are an unprecedented and powerful tool that is highly promising for modeling numerous human genetic diseases in vitro.

\section{Induced pluripotent stem cells for disease modeling and drug testing}

So far, more than 40 iPSC disease models have been successfully generated from patients with genetic diseases [5], and the length of the list keeps increasing. Notable examples of models developed so far are Duchenne and Becker muscular dystrophy [7], Huntington disease [7], Shwachman-Diamond syndrome [7], Lesch-Nyhan syndrome [7], amyotrophic lateral sclerosis [39], spinal muscular atrophy [40], familial dysautonomia [41], dyskeratosis congenital [42], Friedreich's ataxia [43], fragile $\mathrm{X}$ syndrome [44], LEOPARD (lentigines, electrocardiographic conduction abnormalities, ocular hypertelorism, pulmonary stenosis, abnormal genitalia, retarded growth, deafness) syndrome [45], long-QT syndrome [46,47], Rett syndrome [48], and Hutchinson-Gilford progeria [49], although not all of these iPSCs exhibit disease-specific phenotypes. The derivatives of some of these diseasespecific iPSCs have been employed as in vitro disease models to test the phenotype-correcting effects of small numbers of promising drugs, such as neurons differentiated from spinal muscular atrophy-specific iPSCs [40] and Rett syndrome-specific iPSCs [48] and cardiomyocytes differentiated from iPSCs for long-QT syndrome [47], suggesting the probability of their use as platforms for performing high-throughput screenings of large chemical libraries to identify novel drug candidates for these diseases.

\section{Lysosomal storage disease-specific iPSCs and their cellular pathology}

Gaucher disease: the initial proof-of-principle lysosomal storage disease-iPSCs

Since there is no cure for most LSDs in current medicine, LSD-specific iPSCs may provide a unique opportunity for dissecting unexplored disease pathogeneses and identifying new drugs. Several disease-specific iPSCs have 
Table 1. Clinical profiles of common lysosomal storage diseases

\begin{tabular}{|c|c|c|c|c|c|}
\hline Disease & $\begin{array}{l}\text { Gene/defective } \\
\text { protein }\end{array}$ & Function & $\begin{array}{l}\text { Clinical symptoms } \\
\text { (in vivo phenotypes) }\end{array}$ & $\begin{array}{l}\text { Biochemical/cellular } \\
\text { pathology }\end{array}$ & Available therapies ${ }^{a}$ \\
\hline Pompe disease & $\begin{array}{l}\text { GAA/acid alpha- } \\
\text { glucosidase }\end{array}$ & $\begin{array}{l}\text { Degrading glycogen in cellular } \\
\text { vacuoles }\end{array}$ & $\begin{array}{l}\text { Cardiac and respiratory } \\
\text { failure; muscle weakness }\end{array}$ & $\begin{array}{l}\text { Glycogen storage; } \\
\text { autophagic build-up }\end{array}$ & $\begin{array}{l}\text { Myozyme; Lumizyme; } \\
\text { DNJ (trial) }\end{array}$ \\
\hline \multicolumn{6}{|l|}{ Sphingolipidoses } \\
\hline Fabry disease & $\begin{array}{l}\text { GLA/alpha- } \\
\text { galactosidase A }\end{array}$ & $\begin{array}{l}\text { Hydrolyzing the terminal } \\
\text { alpha-galactosyl moieties from } \\
\text { glycolipids and glycoproteins }\end{array}$ & $\begin{array}{l}\text { Cardiovascular problems; } \\
\text { renal failure; pain and } \\
\text { paresthesia in the } \\
\text { extremities }\end{array}$ & $\begin{array}{l}\text { Increase levels of GB3; } \\
\text { laminated alternate } \\
\text { electron-dense } \\
\text { and lucent layers } \\
\text { (Zebra bodies) in the } \\
\text { cytoplasm }\end{array}$ & $\begin{array}{l}\text { Fabrazyme; Replagal; } \\
\text { DGJ (trial) }\end{array}$ \\
\hline Gaucher disease & $\begin{array}{l}\text { GBA/acid beta- } \\
\text { glucocerebrosidase }\end{array}$ & $\begin{array}{l}\text { Cleavage of the } \\
\text { glucosylceramide to ceramide } \\
\text { and glucose }\end{array}$ & $\begin{array}{l}\text { Hepatosplenomegaly; } \\
\text { pancytopenia; skeletal } \\
\text { (type } 1 \text { and } 3 \text { ) or } \\
\text { neurological problems } \\
\text { (type } 2 \text { and } 3 \text { ) }\end{array}$ & $\begin{array}{l}\text { Tubular structures in } \\
\text { arrays inside dilated } \\
\text { lysosomes under EM }\end{array}$ & $\begin{array}{l}\text { Cerezyme; Zavesca } \\
\text { (miglustat; NB-DNJ); } \\
\text { isofagomine (trial) }\end{array}$ \\
\hline $\begin{array}{l}\text { Niemann-Pick } \\
\text { disease, type A } \\
\text { and B }\end{array}$ & $\begin{array}{l}\text { SMPD1/acid } \\
\text { sphingomyelinase }\end{array}$ & $\begin{array}{l}\text { Converting sphingomyelin to } \\
\text { ceramide }\end{array}$ & $\begin{array}{l}\text { Hepatosplenomegaly; } \\
\text { cherry-red maculae; } \\
\text { pneumonia }\end{array}$ & $\begin{array}{l}\text { Abnormal lipid profiles; } \\
\text { lamellar inclusions } \\
\text { under EM }\end{array}$ & $\begin{array}{l}\text { rhASM (for type B, trial, not } \\
\text { published) }\end{array}$ \\
\hline $\begin{array}{l}\text { Metachromatic } \\
\text { leukodystrophy }\end{array}$ & ARSA/arylsufatase A & $\begin{array}{l}\text { Hydrolyzing cerebroside } \\
\text { sulfate to cerebroside and } \\
\text { sulfate }\end{array}$ & $\begin{array}{l}\text { Progressive neurological } \\
\text { dysfunction; } \\
\text { demyelination }\end{array}$ & $\begin{array}{l}\text { Metachromatic } \\
\text { deposits in the nervous } \\
\text { system }\end{array}$ & $\begin{array}{l}\text { BMT (may delay progress); } \\
\text { rhARSA (for those who } \\
\text { have received HSCT, trial, } \\
\text { not published) }\end{array}$ \\
\hline $\begin{array}{l}\text { Krabbe disease } \\
\text { (Globoid cell } \\
\text { leukodystrophy) }\end{array}$ & $\begin{array}{l}\text { GALC/beta- } \\
\text { galactocerebrosidase }\end{array}$ & $\begin{array}{l}\text { Hydrolyzing the } \\
\text { galactose ester bonds of } \\
\text { galactosylceramide }\end{array}$ & $\begin{array}{l}\text { Diffuse neurological } \\
\text { dysfunction; sensorimotor } \\
\text { peripheral neuropathy }\end{array}$ & $\begin{array}{l}\text { Accumulation of } \\
\text { galactosylsphingosine } \\
\text { in all tissues, } \\
\text { filamentous and } \\
\text { curvilinear inclusions }\end{array}$ & HSCT; BMT \\
\hline
\end{tabular}

Mucopolysaccharidoses (MPS): representative types

\begin{tabular}{|c|c|c|c|c|c|}
\hline $\begin{array}{l}\text { Hurler syndrome } \\
\text { (MPS IH) }\end{array}$ & $\begin{array}{l}\text { IDUA/alpha-L- } \\
\text { iduronidase }\end{array}$ & $\begin{array}{l}\text { Hydrolyzes the terminal alpha- } \\
\text { L-iduronic acid residues of the } \\
\text { glycosaminoglycans }\end{array}$ & $\begin{array}{l}\text { Hepatosplenomegaly; } \\
\text { heart diseases; dysostosis } \\
\text { multiplex; mental } \\
\text { retardation }\end{array}$ & $\begin{array}{l}\text { Accumulation of } \\
\text { dermatan sulfate and } \\
\text { heparan sulfate }\end{array}$ & HSCT; Aldurazyme \\
\hline $\begin{array}{l}\text { Hunter syndrome } \\
\text { (MPS II) }\end{array}$ & IDS/iduronate sulfatase & $\begin{array}{l}\text { Lysosomal degradation of } \\
\text { heparan sulfate and dermatan } \\
\text { sulfate }\end{array}$ & $\begin{array}{l}\text { Growth deficiency; coarse } \\
\text { face; stiff joints; mental } \\
\text { retardation }\end{array}$ & $\begin{array}{l}\text { Accumulation of } \\
\text { dermatan sulfate and } \\
\text { heparan sulfate }\end{array}$ & BMT; Elaprase \\
\hline $\begin{array}{l}\text { Sanfilippo } \\
\text { syndrome B (MPS } \\
\text { IIIB) }\end{array}$ & $\begin{array}{l}\text { NAGLU/alpha-N- } \\
\text { acetylglucosaminidase }\end{array}$ & $\begin{array}{l}\text { Lysosomal degradation of } \\
\text { heparan sulfate }\end{array}$ & $\begin{array}{l}\text { Severe } \\
\text { neurodegeneration; } \\
\text { coarse face; mild } \\
\text { organomegaly }\end{array}$ & $\begin{array}{l}\text { Accumulation of } \\
\text { heparan sulfate; } \\
\text { abnormal Ca+2 } \\
\text { homeostasis; Golgi } \\
\text { abnormalities; } \\
\text { abnormal neurite } \\
\text { outgrowth }\end{array}$ & Miglustat (NB-DNJ, trail) \\
\hline $\begin{array}{l}\text { Sly syndrome } \\
\text { (MPS VII) }\end{array}$ & $\begin{array}{l}\text { GUSB/beta- } \\
\text { glucuronidase }\end{array}$ & $\begin{array}{l}\text { Lysosomal degradation of } \\
\text { glucuronic acid-containing } \\
\text { glycosaminoglycans }\end{array}$ & $\begin{array}{l}\text { Heart disease; } \\
\text { dysostosis multiplex; } \\
\text { hepatosplenomegaly; } \\
\text { hydrops fetalis; mental } \\
\text { retardation }\end{array}$ & $\begin{array}{l}\text { Progressive lysososmal } \\
\text { storage in many } \\
\text { tissues because of } \\
\text { accumulation of } \\
\text { dermatan sulfate and } \\
\text { heparan sulfate }\end{array}$ & BMT \\
\hline
\end{tabular}


Table 1. Continued

\begin{tabular}{|c|c|c|c|c|c|}
\hline Disease & $\begin{array}{l}\text { Gene/defective } \\
\text { protein }\end{array}$ & Function & $\begin{array}{l}\text { Clinical symptoms } \\
\text { (in vivo phenotypes) }\end{array}$ & $\begin{array}{l}\text { Biochemical/cellular } \\
\text { pathology }\end{array}$ & Available therapies $^{\mathrm{a}}$ \\
\hline \multicolumn{6}{|c|}{ Lipid storage disease } \\
\hline $\begin{array}{l}\text { Niemann-Pick } \\
\text { disease, type C }\end{array}$ & NPC1/NPC1 protein & $\begin{array}{l}\text { Regulating intracellular } \\
\text { cholesterol trafficking }\end{array}$ & $\begin{array}{l}\text { Hepatosplenomegaly; } \\
\text { neurological deterioration }\end{array}$ & $\begin{array}{l}\text { Low-cholesterol } \\
\text { esterification; lamellar } \\
\text { inclusions in foam cells }\end{array}$ & $\begin{array}{l}\text { Zavesca (miglustat; } \\
\text { NB-DNJ) }\end{array}$ \\
\hline $\begin{array}{l}\text { Ceroid } \\
\text { lipofuschinosis, } \\
\text { neuronal, type } 1\end{array}$ & $\begin{array}{l}\text { PPT1/palmitoyl-protein } \\
\text { thioesterase }\end{array}$ & $\begin{array}{l}\text { Removing palmitate from } \\
\text { cysteine residues during } \\
\text { lysosomal degradation }\end{array}$ & $\begin{array}{l}\text { Myoclonus; spasticity; } \\
\text { ophthalmic problems; } \\
\text { mental deterioration }\end{array}$ & $\begin{array}{l}\text { Granular osmiophilic } \\
\text { cytoplasmic deposits in } \\
\text { cells under EM }\end{array}$ & $\begin{array}{l}\text { Cystagon (cysteamine } \\
\text { bitartrate) combined with } \\
\mathrm{N} \text {-acetylcysteine (trial); } \\
\text { neural stem cells (trial) }\end{array}$ \\
\hline \multicolumn{6}{|l|}{ Mucolipidosis } \\
\hline I-cell disease & $\begin{array}{l}\text { GNPTAB/N- } \\
\text { Acetylglucosaminyl- } \\
\text { phosphotransferase } \\
\text { alpha and beta } \\
\text { subunits }\end{array}$ & $\begin{array}{l}\text { Catalyzing the synthesis of } \\
\text { the M-6-P determinant on } \\
\text { lysosomal hydrolases }\end{array}$ & $\begin{array}{l}\text { Alveolar ridge } \\
\text { hypertrophy; dysostosis } \\
\text { multiplex; heart failure; } \\
\text { joint limitation; thick tight } \\
\text { skin; mental retardation }\end{array}$ & $\begin{array}{l}\text { Increased lysosomal } \\
\text { enzyme secretion; } \\
\text { membrane-bound } \\
\text { vacuoles containing } \\
\text { electron-lucent } \\
\text { or fibrillogranular } \\
\text { contents }\end{array}$ & BMT \\
\hline \multicolumn{6}{|l|}{ Oligosaccharidosis } \\
\hline Fucosidosis & $\begin{array}{l}\text { FUCA1/alpha-L- } \\
\text { fucosidase }\end{array}$ & $\begin{array}{l}\text { Degrading fucose-containing } \\
\text { glycoproteins and glycolipids }\end{array}$ & $\begin{array}{l}\text { Angiokeratoma; } \\
\text { psychomotor retardation; } \\
\text { coarse face; dysostosis } \\
\text { multiplex }\end{array}$ & $\begin{array}{l}\text { Increased } \\
\text { oligosaccharide } \\
\text { secretion; elevated } \\
\text { sweat chloride; } \\
\text { vacuolated } \\
\text { lymphocytes }\end{array}$ & HSCT; BMT \\
\hline \multicolumn{6}{|c|}{ Transport defects through the lysosomal membrane } \\
\hline Cystinosis & CTNS/cystinosin & $\begin{array}{l}\text { Transporting cystine out of } \\
\text { lysosomes }\end{array}$ & $\begin{array}{l}\text { Failure to thrive; } \\
\text { renal tubular } \\
\text { Fanconi syndrome; } \\
\text { hepatosplenomegaly; } \\
\text { skeletal problems }\end{array}$ & $\begin{array}{l}\text { Characteristic crystals } \\
\text { within lysosomes } \\
\text { causing cell expansion }\end{array}$ & $\begin{array}{l}\text { Cystagon (cysteamine } \\
\text { bitartrate) }\end{array}$ \\
\hline \multicolumn{6}{|c|}{ Defective vesicular traffic } \\
\hline $\begin{array}{l}\text { Chediak-Higashi } \\
\text { syndrome }\end{array}$ & CHS1/LYST protein & $\begin{array}{l}\text { Regulating protein trafficking } \\
\text { to and from lysosomes }\end{array}$ & $\begin{array}{l}\text { Recurrent pyogenic } \\
\text { infections; } \\
\text { ophthalmic problems; } \\
\text { hepatosplenomegaly; } \\
\text { neurological dysfunction }\end{array}$ & $\begin{array}{l}\text { Giant granules in } \\
\text { muscle cells; giant } \\
\text { lysosomes; altered } \\
\text { vesicular fusion; } \\
\text { defective antigen } \\
\text { presentation }\end{array}$ & BMT; HSCT \\
\hline
\end{tabular}

aRegardless of their efficacy, only drugs that have been approved or are undergoing clinical trials are listed. BMT, bone marrow transplantation; DGJ, 1-deoxygalactonojirimycin; DNJ, 1-deoxynojirimycin; EM, electron microscopy; GB3, globotriaosylceramide; HSCT, hematopoietic stem cell therapy; M-6-P, mannose-6-phosphate; NB-DNJ, N-butyl-1-deoxynojirimycin; rhARSA, recombinant arylsufatase A; rhASM, recombinant acid sphingomyelinase.

been successfully generated from either mouse models for LSDs or patients with LSDs (Table 2). The iPSCs derived from a patient with Gaucher disease type III accounted for perhaps the first reported human LSDiPSC line established [7], although few Gaucher diseasespecific phenotypes have been described in detail.

\section{Mouse lysosomal storage disease-specific iPSCs}

Using tail-tip fibroblasts from mouse models of Fabry disease [8], Krabbe disease [8], MPS VII [8], and Pompe disease [9], Eto and colleagues have generated corresponding disease-specific iPSCs and characterized them. In addition to reporting deficient enzyme activities and substrate accumulation in these cells, the authors reported impaired embryonic body formation in MPS VII-specific iPSCs [8], a novel phenotype that, as the authors suggested, is possibly attributed to an elevated level of hyaluronic acid and may not be easily identified without using disease-specific iPSCs. According to the authors, two in vivo phenotypes are possibly related to 
Table 2. Disease modeling and drug testing of lysosomal storage disease induced pluripotent stem cells recorded in the literature

\begin{tabular}{|c|c|c|c|c|c|c|}
\hline Disease & Species & Original cell type & $\begin{array}{l}\text { Cell type } \\
\text { of interest }\end{array}$ & $\begin{array}{l}\text { Disease } \\
\text { phenotype }^{a}\end{array}$ & $\begin{array}{l}\text { Drug } \\
\text { testing }\end{array}$ & References \\
\hline Pompe disease & Mouse & Fibroblasts & Skeletal muscle cells & Glycogen accumulation & No & [9] \\
\hline Pompe disease & Human & Fibroblasts & Cardiomyocytes & $\begin{array}{l}\text { Glycogen storage and abnormal } \\
\text { morphology and functions of } \\
\text { mitochondria }\end{array}$ & Yes & [10] \\
\hline Fabry disease & Mouse & Fibroblasts & Cardiomyocytes & Gb3 accumulation & No & [8] \\
\hline Krabbe disease & Mouse & Fibroblasts & Neural stem cells & $\begin{array}{l}\text { Reduced beta-galactocerebrosidase } \\
\text { activity }\end{array}$ & No & [8] \\
\hline $\begin{array}{l}\text { Gaucher disease } \\
\text { (type III) }\end{array}$ & Human & Fibroblasts & ND & ND & No & [7] \\
\hline $\begin{array}{l}\text { Hurler syndrome } \\
\text { (MPS 1H) }\end{array}$ & Human & $\begin{array}{l}\text { Keratinocytes and bone } \\
\text { marrow mesenchymal } \\
\text { stem cells }\end{array}$ & Hematopoietic cells & $\begin{array}{l}\text { Lysosomal storage of } \\
\text { glycosaminoglycans }\end{array}$ & No & [11] \\
\hline MPS IIIB & Human & Fibroblasts & $\begin{array}{l}\text { Neural stem cells } \\
\text { and neurons }\end{array}$ & $\begin{array}{l}\text { Storage vesicles associated with } \\
\text { disorganized Golgi complex }\end{array}$ & Yes & [12] \\
\hline MPS VII & Mouse & Fibroblasts & Unknown & $\begin{array}{l}\text { Elevated levels of hyaluronic } \\
\text { acid and impaired formation of } \\
\text { embryoid bodies }\end{array}$ & No & [8] \\
\hline
\end{tabular}

${ }^{a}$ Except for the impaired embryoid body formation found in mucopolysaccharidosis (MPS) VII induced pluripotent stem cells (iPSCs), all lysosomal storage disease iPSC phenotypes have been reported in patient tissues or cells. Gb3, globotriaosylceramide; ND, not described.

impaired embryoid body formation in MPS VII iPSCs: (1) the lower-than-expected $25 \%$ of MPS VII $\left(\mathrm{GUSB}^{-/-}\right)$ mice born from heterozygous mating based on Mendelian inheritance and (2) hydrops fetalis, which is known to be relatively common in patients with MPS VII [8]. Moreover, the same group has shown that mouse Pompe disease iPSCs can be differentiated into skeletal muscles that are positively stained for myosin heavy chain, accumulate glycogen in lysosomes, and have typical ultrastructural features, including Z-, I-, A-, and $\mathrm{H}$-bands [9]. Such an achievement is remarkable because skeletal muscles are among the most difficult mammalian cell types to obtain from in vitro differentiation of pluripotent stem cells [50].

\section{Human Pompe disease}

Using a unique acid alpha-glucosidase (GAA) rescuebased strategy and fibroblasts from two patients with Pompe disease, we also successfully generated four Pompe disease-specific iPSC lines [10]. All of these lines exhibit Pompe disease-specific phenotypes, such as very low GAA activity and high glycogen content, and can be differentiated into cardiomyocytes that have disarrayed myofibrils and abundant glycogen-containing vacuoles. Unexpectedly, we also found that Pompe disease iPSCs have defective cellular respiration (whereas ESCs and normal iPSCs do not) and this is supported by our finding that the mitochondria of cardiomyocytes derived from Pompe disease iPSCs exhibit abnormal morphology. We have tested several drugs/chemicals by using Pompe disease iPSC-derived cardiomyocytes and found that glycogen accumulation can be reduced by recombinant GAA and that the deteriorated mitochondrial functions can be partially rescued by L-carnitine. In addition, using comparative transcriptome analysis, we have identified six marker genes whose expression robustly correlates with the therapeutic effect of recombinant GAA or Lcarnitine [10]. We are currently using these Pompe disease iPSCs to test the therapeutic effects of other compounds (for example, autophagy inhibitors) because excessive autophagic build-ups have been documented as an important feature of cells of patients with Pompe disease $[51,52]$.

\section{Human mucopolysaccharidosis $1 \mathrm{H}$}

Presuming that iPSC-derived hematopoietic cells may have fewer immunological complications than regular donor cells in hematopoietic cell transplantation (HCT), Tolar and colleagues [11] generated iPSCs from a patient with MPS type IH, a severe form of alpha-L-iduronidase deficiency that can be treated by HCT but not by ERT, and successfully corrected the gene defect by using iPSCs transduced with lentivirus harboring the wild-type gene (called IDUA) encoding this enzyme. The authors reported that alpha-L-iduronidase activity is not required for stem cell renewal and that MPS IH-iPSCs already have lysosomal storage of GAG. Moreover, MPS IHiPSCs can be differentiated into hematopoietic progeny 
with a colony-forming capacity comparable to those of IDUA-corrected and wild-type iPSC-derived hematopoietic progeny. The authors emphasized the advantages of iPSCs for possible application in HCT; for example, iPSCs are more feasible for long-term culture, and gene correction of iPSCs is easier than that of hematopoietic stem cells, which are more sensitive to ex vivo manipulation. Clarification of whether such IDUA-corrected iPSCs can be used for therapeutic purposes without immunological complications awaits further studies.

\section{Human mucopolysaccharidosis IIIB}

A prominent advantage of iPSC technology is that it offers access to patient neuronal cells, because neuronal cells are not difficult to derive from iPSCs [40]. This is critical for studying diseases - such as MPS type IIIB, a fatal LSD caused by the deficiency of $\alpha$-N-acetylglucosaminidase - that involve primarily the central nervous system. Lemonnier and colleagues [12] successfully generated MPS IIIB-iPSCs and demonstrated that severe cellular pathology, including storage vesicles and disorganized Golgi complex, exists in undifferentiated iPSCs and differentiated neurons but not in neuronal progenitors. It is worth noting that the authors used exogenous recombinant enzyme to complement the enzymatic defect in order to clone MPS IIIB-iPSCs efficiently, an approach similar to our rescue strategy mentioned above [10]. Considering quantitative reverse transcription-polymerase chain reaction and Western blot results, the authors suggested that accumulation of heparin sulfate modifies the extracellular matrix constituents and related signaling pathways, which cause disorganization of Golgi architecture. Mild phenotypes in floating neuronal progenitors were explained by their non-adherent nature and less dependence on extracellular matrix-bound signals.

\section{Strategies for drug design and screening for lysosomal storage diseases based on iPSCs \\ 1. Pharmacological chaperones}

The introduction above reveals that researchers around the world have generated proof-of-principle patientspecific iPSCs for several LSDs. Most of the published results of LSD-iPSC research have not advanced to the stage of drug design or medium-scale drug testing, not to mention attempts at high-throughput screening of chemical libraries for novel drug targeting of LSDs using iPSCs. However, compared with other disease iPSCs, LSD-iPSCs are more suitable for the purpose of drug design and high-throughput chemical screening because they are caused by defects of lysosomal enzymes, whose activities are measurable in vitro on a large-scale basis and the accumulated lysosomal substrates in LSDs can be assayed by either biochemical or immunocytochemical methods. Moreover, novel drugs can be designed or identified to enhance the activity, stability, or trafficking of mutant enzymes by assisting their folding or to target the pathways that synthesize the accumulated substrates. One class of small molecules termed pharmacological chaperones, which are reversible and competitive inhibitors of their target enzymes, may be suitable drug candidates.

In the past decade, many pharmacological chaperones have been developed to target the affected enzymes in various LSDs; this topic has been extensively reviewed elsewhere [22,53]. The chaperones can be taken orally, cross the blood-brain barrier, and have biodistributions that are better than those of ERT. Some of these chaperones are already prescribed formally in clinical practice [53]. The common strategies for identifying candidate pharmacological chaperones include both looking for molecules that have structural homology with the target natural substrates [54] and direct highthroughput screenings of compound libraries [55]. The methodology comprises initial in vitro assays such as enzyme inhibition assays in different $\mathrm{pH}$ environments $[22,56]$, physical stability assays $[22,57]$ using recombinant wild-type enzymes, and subsequent cell-based assays to estimate the effect of chaperones on enzyme activity and enzyme trafficking [22]. Chaperones identified to work for wild-type enzymes are not necessarily helpful for mutant enzymes and need be tested in different patients' fibroblasts or cell lines to evaluate the therapeutic effect [22]. For this purpose, LSD-iPSCs can offer a limitless source of human diseased cells containing various mutations for the second-round drug screening that is based on various cell-based assays, especially for those biochemical or cellular phenotypes seen in distinct differentiated cells (for example, neurons) that can be obtained only through directed differentiation of iPSCs. It is also theoretically possible that LSD-specific iPSCs can be used directly in first-round or even large-scale cell-based screening using similar strategies because a number of these cell-based assays have been successfully developed to meet the requirements of high-throughput screening formats [22], including the high-content imaging platforms [58] to evaluate enzyme trafficking.

\section{Proteostasis regulators and other compounds}

In addition to pharmacological chaperones, other ways to improve the protein folding of mutant enzymes are available. Two alternative methods have been developed [59-61]. First, it has been demonstrated [59,60] that two common L-type calcium channel blockers [59], either diltiazem or verapamil, and ryanodine receptor blockers, such as lacidipine [60], can partially restore the activity of two glucocerebrosidase mutants in fibroblasts derived from patients with Gaucher disease; the authors suggested 
that these drugs exert their effects by upregulating a subset of molecular chaperones, such as BiP and Hsp40, which in turn ameliorate the capacity of the endoplasmic reticulum to rescue misfolded mutant enzymes. Second, $\mathrm{Mu}$ and colleagues [61] showed that two proteostasis regulators, celastrol and MG-132, can increase the concentrations and functions of mutant enzymes associated with two LSDs: Gaucher disease and TaySachs disease. Moreover, the authors demonstrated that the combined use of pharmacological chaperones and such proteostasis regulators can generate a synergistic rescue effect on mutant enzymes in cells derived from patients with either LSD [61]. A more comprehensive review on the multiple aspects of protein folding or degradation that are related to pharmacological intervention can be found elsewhere [62]. Obviously, future efforts should be aimed at identifying more compounds of these two classes by using LSD-iPSCs and proving that the chemicals identified by using these strategies can be successfully applied next in animal studies and finally in clinical trials.

On the other hand, novel adjunct therapies also deserve to be developed to better preserve various cellular functions after correcting the disease-specific cellular pathology in different organelles (for example, the autophagic build-up and mitochondrial dysfunction in Pompe disease [52] and Golgi abnormalities in MPS type IIIB [12]). In this respect, candidate drugs may include some well-known autophagy inhibitors used in clinical trials [63], drugs or nutrient supplements [64] for treating mitochondrial dysfunction, and chemicals known to reverse endoplasmic reticulum-to-Golgi trafficking defects [65]. High-throughput screening of chemical libraries for this purpose is also a possibility because similar approaches in other fields using ESCs/iPSCs have been reported [66,67] and because proper screening-based formats of some amenable biochemical and cellular assays for such organelle dysfunctions have been reported $[65,68,69]$ and may be exploited in the iPSC system as well. However, this is still a challenging task because successful purification of differentiated cells is a prerequisite and iPSCs may need to be passaged as single cells that can survive. A Rho-associated kinase inhibitor [70] or Accutase (Millipore Corporation, Billerica, MA, USA) [71] may be helpful to achieve this goal.

\section{Caveats in drug screening for lysosomal storage diseases based on iPSCs}

Several caveats are associated with using patient-specific iPSCs for drug screening [72,73]. First, mutational heterogeneity exists in most LSDs, but establishment of patient-specific iPSCs is time-consuming and laborintensive. Thus, it may not be practical for a single laboratory to generate patient-specific iPSCs for all of the mutations found in a single disease, and determining whether the drugs identified to work for certain mutants are also helpful for other mutants would be a problem. Second, as seen in other classic cell-based platforms for drug screening, there is no guarantee that drug candidates identified from in vitro assays can be used successfully in vivo. Third, to test drugs that target the phenotypes existing only in differentiated cells (for example, electrophysiological anomalies in cardiomyocytes), a highly homogenous cell population differentiated from iPSCs may be needed to obtain consistent readouts [22]. Therefore, extensive collaborations among different laboratories on the basis of consensus and standardized protocols for generating iPSC lines and comparing drug effects will be essential. Moreover, other assays and systems - such as using LSD animal models to determine the pharmacokinetics, pharmacodynamics, and toxicities of candidate drugs - should always be used to complement iPSC-based drug screening. Finally, a more efficient and economic, and less time-consuming, set of protocols for obtaining homogenous differentiated cell types of interest in LSDs should be established in advance.

\section{Conclusions}

iPSC technology offers a revolutionary method for modeling LSDs and other diseases and the hope of future cell-based therapy. Since most LSDs are characterized by defects in enzymes whose activities are readily measurable in vitro, disease-specific iPSCs offer an ideal in vitro cellular system for designing LSD-specific pharmacological chaperones and for possible high-throughput compound screening. However, the application of iPSC technology for drug discovery is still at an early stage, and several major challenges - such as the difficulty of generating highly enriched disease-relevant desired cell types in large quantities from diseased iPSCs, the influence of culture and reprogramming artifacts on cell behavior, and the inability to recapitulate disease features in the diseased iPSC derivatives - must be resolved before it can be rendered an efficient and robust system for developing drugs targeting LSDs. With the advances in generating transgenic human pluripotent stem cells [74], the difficulty of enriching desired cell types from differentiating diseased iPSCs is likely to be resolved soon as specific cell types can be purified from cell mixtures by lineage-specific genetic markers or directly differentiated by ectopically expressed lineage determinant(s) in diseased iPSCs or both. In addition to iPSCs, induced somatic cells, which directly convert from fibroblasts by defined transcription factors [75,76], can potentially provide another source of disease-relevant cell types for the purpose of disease modeling. The advantage of the direct cell fate conversion technology is that a desired cell type can be directly generated from a patient's fibroblasts 
by using a fast and simple protocol without the need of further cell purification. However, it has been suggested that the conventional pathological phenotypes of certain forms of diseases depend on cell interaction and may require a longer time to arise in a disease iPSC model $[77,78]$. Nevertheless, the disease process might be initiated much earlier than the emergence of clinical symptoms. Therefore, iPSC disease modeling can potentially provide an opportunity for earlier identification of phenotypic changes in diseases of interest. Despite these concerns, evidence supporting iPSC disease modeling of genetic diseases as a valuable in vitro cellular system through which to understand the mechanisms underlining the pathologies of diseases and future drug discovery has rapidly accumulated in the past few years.

This article is part of a thematic series on Stem cell research in the Asia-Pacific edited by Oscar Lee, Songtao Shi, Yufang Shi and Ying Jin. Other articles in the series can be found online at http://stemcellres.com/series/asiapacific

\section{Abbreviations}

ERT, enzyme replacement therapy; ESC, embryonic stem cell; GAA, acid alpha-glucosidase; GAG, glycosaminoglycans; HCT, hematopoietic cell transplantation; iPSC, induced pluripotent stem cell; LSD, lysosomal storage disease; MPS, mucopolysaccharidosis

\section{Competing interests}

The authors declare that they have no competing interests.

\section{Author details}

'Department of Medical Research and Department of Pediatrics, National Taiwan University Hospital, No. 7, Chung Shan S. Rd., Zhongshan, Taipei 100, Taiwan. ${ }^{2}$ Genomics Research Center, Academia Sinica, No. 128, Sec. 2, Academia Road, Nankang, Taipei 115, Taiwan. ${ }^{3}$ nnstitute of Cellular and Organismic Biology, Academia Sinica, No. 128, Sec. 2, Academia Road, Nankang, Taipei 115, Taiwan.

Published: 28 August 2012

\section{References}

1. Takahashi K, Yamanaka S: Induction of pluripotent stem cells from mouse embryonic and adult fibroblast cultures by defined factors. Cell 2006, 126:663-676.

2. Takahashi K, Tanabe K, Ohnuki M, Narita M, Ichisaka T, Tomoda K, Yamanaka S: Induction of pluripotent stem cells from adult human fibroblasts by defined factors. Cell 2007, 131:861-872.

3. Hoffman LM, Carpenter MK: Characterization and culture of human embryonic stem cells. Nat Biotechnol 2005, 23:699-708.

4. Chen HF, Chuang CY, Lee WC, Huang HP, Wu HC, Ho HN, Chen YJ, Kuo HC: Surface marker epithelial cell adhesion molecule and E-cadherin facilitate the identification and selection of induced pluripotent stem cells. Stem Cell Rev 2011, 7:722-735.

5. Robinton DA, Daley GQ: The promise of induced pluripotent stem cells in research and therapy. Nature 2012, 481:295-305.

6. Meikle PJ, Hopwood JJ, Clague AE, Carey WF: Prevalence of lysosomal storage disorders. JAMA 1999, 281:249-254.

7. Park IH, Arora N, Huo H, Maherali N, Ahfeldt T, Shimamura A, Lensch MW, Cowan C, Hochedlinger K, Daley GQ: Disease-specific induced pluripotent stem cells. Cell 2008, 134:877-886.

8. Meng XL, Shen JS, Kawagoe S, Ohashi T, Brady RO, Eto Y: Induced pluripotent stem cells derived from mouse models of lysosomal storage disorders. Proc Natl Acad Sci U S A 2010, 107:7886-7891.

9. Kawagoe S, Higuchi T, Meng XL, Shimada Y, Shimizu H, Hirayama R, Fukuda T,
Chang H, Nakahata T, Fukada S, Ida H, Kobayashi H, Ohashi T, Eto Y: Generation of induced pluripotent stem (iPS) cells derived from a murine model of Pompe disease and differentiation of Pompe-iPS cells into skeletal muscle cells. Mol Genet Metab 2011, 104:123-128.

10. Huang HP, Chen PH, Hwu WL, Chuang CY, Chien YH, Stone L, Chien CL, Li LT, Chiang SC, Chen HF, Ho HN, Chen CH, Kuo HC: Human Pompe diseaseinduced pluripotent stem cells for pathogenesis modeling, drug testing and disease marker identification. Hum Mol Genet 2011, 20:4851-4864.

11. Tolar J, Park IH, Xia L, Lees CJ, Peacock B, Webber B, McElmurry RT, Eide CR, Orchard PJ, Kyba M, Osborn MJ, Lund TC, Wagner JE, Daley GQ, Blazar BR: Hematopoietic differentiation of induced pluripotent stem cells from patients with mucopolysaccharidosis type I (Hurler syndrome). Blood 2010, 117:839-847.

12. Lemonnier T, Blanchard S, Toli D, Roy E, Bigou S, Froissart R, Rouvet I, Vitry S, Heard JM, Bohl D: Modeling neuronal defects associated with a lysosomal disorder using patient-derived induced pluripotent stem cells. Hum Mol Genet 2011, 20:3653-3666.

13. Luzio JP, Pryor PR, Bright NA: Lysosomes: fusion and function. Nat Rev Mol Cell Biol 2007, 8:622-632.

14. Parkinson-Lawrence EJ, Shandala T, Prodoehl M, Plew R, Borlace GN, Brooks DA: Lysosomal storage disease: revealing lysosomal function and physiology. Physiology (Bethesda) 2010, 25:102-115.

15. Durand P: Recent progress of lysosomal diseases. Enzyme 1987, 38:256-261.

16. Ward DM, Griffiths GM, Stinchcombe JC, Kaplan J: Analysis of the lysosomal storage disease Chediak-Higashi syndrome. Traffic 2000, 1:816-822.

17. Feng L, Novak EK, Hartnell LM, Bonifacino JS, Collinson LM, Swank RT: The Hermansky-Pudlak syndrome 1 (HPS1) and HPS2 genes independently contribute to the production and function of platelet dense granules, melanosomes, and lysosomes. Blood 2002, 99:1651-1658.

18. Lachmann $\mathrm{RH}$ : Enzyme replacement therapy for lysosomal storage diseases. Curr Opin Pediatr 2011, 23:588-593.

19. Begley DJ, Pontikis CC, Scarpa M: Lysosomal storage diseases and the blood-brain barrier. Curr Pharm Des 2008, 14:1566-1580.

20. Malatack JJ, Consolini DM, Bayever E: The status of hematopoietic stem cell transplantation in lysosomal storage disease. Pediatr Neurol 2003, 29:391-403.

21. Ficicioglu C: Review of miglustat for clinical management in Gaucher disease type 1. Ther Clin Risk Manag 2008, 4:425-431.

22. Valenzano KJ, Khanna R, Powe AC, Boyd R, Lee G, Flanagan JJ, Benjamin ER: Identification and characterization of pharmacological chaperones to correct enzyme deficiencies in lysosomal storage disorders. Assay Drug Dev Technol 2011, 9:213-235.

23. Pineda M, Wraith JE, Mengel E, Sedel F, Hwu WL, Rohrbach M, Bembi B, Walterfang M, Korenke GC, Marquardt T, Luzy C, Giorgino R, Patterson MC: Miglustat in patients with Niemann-Pick disease Type C (NP-C): a multicenter observational retrospective cohort study. Mol Genet Metab 2009, 98:243-249.

24. Yu J, Vodyanik MA, Smuga-Otto K, Antosiewicz-Bourget J, Frane JL, Tian S, Nie J, Jonsdottir GA, Ruotti V, Stewart R, Slukvin II, Thomson JA: Induced pluripotent stem cell lines derived from human somatic cells. Science 2007, 318:1917-1920.

25. Wernig M, Meissner A, Foreman R, Brambrink T, Ku M, Hochedlinger K, Bernstein $B E$, Jaenisch $\mathrm{R}$ : In vitro reprogramming of fibroblasts into a pluripotent ES-cell-like state. Nature 2007, 448:318-324.

26. Park IH, Zhao R, West JA, Yabuuchi A, Huo H, Ince TA, Lerou PH, Lensch MW, Daley GQ: Reprogramming of human somatic cells to pluripotency with defined factors. Nature 2008, 451:141-146.

27. Feng $\mathrm{B}, \mathrm{Ng} \mathrm{JH}$, Heng JC, $\mathrm{Ng} \mathrm{HH}$ : Molecules that promote or enhance reprogramming of somatic cells to induced pluripotent stem cells. Cell Stem Cell 2009, 4:301-312.

28. Nakhaei-Rad S, Bahrami AR, Mirahmadi M, Matin MM: New windows to enhance direct reprogramming of somatic cells towards induced pluripotent stem cells. Biochem Cell Bio/ 2012, 90:115-123.

29. Zhu S, Wei W, Ding S: Chemical strategies for stem cell biology and regenerative medicine. Annu Rev Biomed Eng 2011, 13:73-90.

30. Woltjen K, Michael IP, Mohseni P, Desai R, Mileikovsky M, Hämäläinen R, Cowling R, Wang W, Liu P, Gertsenstein M, Kaji K, Sung HK, Nagy A: piggyBac transposition reprograms fibroblasts to induced pluripotent stem cells. Nature 2009, 458:766-770.

31. Kim D, Kim CH, Moon Jl, Chung YG, Chang MY, Han BS, Ko S, Yang E, Cha KY, Lanza R, Kim KS: Generation of human induced pluripotent stem cells by 
direct delivery of reprogramming proteins. Cell Stem Cell 2009, 4:472-476.

32. Warren L, Manos PD, Ahfeldt T, Loh YH, Li H, Lau F, Ebina W, Mandal PK, Smith ZD, Meissner A, Daley GQ, Brack AS, Collins JJ, Cowan C, Schlaeger TM,Rossi $D J$ : Highly efficient reprogramming to pluripotency and directed differentiation of human cells with synthetic modified mRNA. Cell Stem Cell 2010, 7:618-630

33. Miyoshi N, Ishii H, Nagano H, Haraguchi N, Dewi DL, Kano Y, Nishikawa S, Tanemura M, Mimori K, Tanaka F, Saito T, Nishimura J, Takemasa I, Mizushima T, kkeda M, Yamamoto H, Sekimoto M, Doki Y, Mori M: Reprogramming of mouse and human cells to pluripotency using mature microRNAs. Cell Stem Cell 2011, 8:633-638.

34. Fusaki N, Ban H, Nishiyama A, Saeki K, Hasegawa M: Efficient induction of transgene-free human pluripotent stem cells using a vector based on Sendai virus, an RNA virus that does not integrate into the host genome. Proc Jpn Acad Ser B Phys Biol Sci 2009, 85:348-362.

35. Kiskinis E, Eggan K: Progress toward the clinical application of patientspecific pluripotent stem cells. J Clin Invest 2010, 120:51-59.

36. Zhao T, Zhang ZN, Rong Z, XU Y: Immunogenicity of induced pluripotent stem cells. Nature 2011, 474:212-215.

37. Okita K, Nagata N, Yamanaka S: Immunogenicity of induced pluripotent stem cells. Circ Res 2011, 109:720-721.

38. Hanna J, Wernig M, Markoulaki S, Sun CW, Meissner A, Cassady JP, Beard C, Brambrink T, Wu LC, Townes TM, Jaenisch R: Treatment of sickle cell anemia mouse model with iPS cells generated from autologous skin. Science 2007, 318:1920-1923.

39. Dimos JT, Rodolfa KT, Niakan KK, Weisenthal LM, Mitsumoto H, Chung W, Croft GF, Saphier G, Leibel R, Goland R, Wichterle H, Henderson CE, Eggan K: Induced pluripotent stem cells generated from patients with ALS can be differentiated into motor neurons. Science 2008, 321:1218-1221.

40. Ebert AD, Yu J, Rose FF Jr., Mattis VB, Lorson CL, Thomson JA, Svendsen CN: Induced pluripotent stem cells from a spinal muscular atrophy patient. Nature 2009, 457:277-280.

41. Lee G, Papapetrou EP, Kim H, Chambers SM, Tomishima MJ, Fasano CA, Ganat YM, Menon J, Shimizu F, Viale A, Tabar V, Sadelain M, Studer L: Modelling pathogenesis and treatment of familial dysautonomia using patientspecific iPSCs. Nature 2009, 461:402-406.

42. Agarwal S, Loh YH, McLoughlin EM, Huang J, Park IH, Miller JD, Huo H, Okuka M, Dos Reis RM, Loewer S, Ng HH, Keefe DL, Goldman FD, Klingelhutz AJ, Liu L, Daley GQ: Telomere elongation in induced pluripotent stem cells from dyskeratosis congenita patients. Nature 2010, 464:292-296.

43. Ku S, Soragni E, Campau E, Thomas EA, Altun G, Laurent LC, Loring JF, Napierala M, Gottesfeld JM: Friedreich's ataxia induced pluripotent stem cells model intergenerational GAATTC triplet repeat instability. Cell Stem Cell 2010, 7:631-637.

44. Urbach A, Bar-Nur O, Daley GQ, Benvenisty N: Differential modeling of fragile $X$ syndrome by human embryonic stem cells and induced pluripotent stem cells. Cell Stem Cell 2010, 6:407-411.

45. Carvajal-Vergara X, Sevilla A, D'Souza SL, Ang YS, Schaniel C, Lee DF, Yang L, Kaplan AD, Adler ED, Rozov R, Ge Y, Cohen N, Edelmann L, Chang B,Waghray A, Su J, Pardo S, Lichtenbelt KD, Tartaglia M, Gelb BD, Lemischka IR: Patientspecific induced pluripotent stem-cell-derived models of LEOPARD syndrome. Nature 2010, 465:808-812.

46. Moretti A, Bellin M, Welling A, Jung CB, Lam JT, Bott-Flügel L, Dorn T, Goedel A, Höhnke C, Hofmann F, Seyfarth M, Sinnecker D, Schömig A, Laugwitz KL: Patient-specific induced pluripotent stem-cell models for long-QT syndrome. N Engl J Med 2010, 363:1397-1409.

47. Itzhaki I, Maizels L, Huber I, Zwi-Dantsis L, Caspi O, Winterstern A, Feldman O, Gepstein A, Arbel G, Hammerman H, Boulos M, Gepstein L: Modelling the long QT syndrome with induced pluripotent stem cells. Nature 2011, 471:225-229.

48. Marchetto MC, Carromeu C, Acab A, Yu D, Yeo GW, Mu Y, Chen G, Gage FH, Muotri AR: A model for neural development and treatment of Rett syndrome using human induced pluripotent stem cells. Cell 2010, 143:527-539.

49. Zhang J, Lian Q, Zhu G, Zhou F, Sui L, Tan C, Mutalif RA, Navasankari R, Zhang $Y$, Tse HF, Stewart CL, Colman A: A human iPSC model of Hutchinson Gilford Progeria reveals vascular smooth muscle and mesenchymal stem cell defects. Cell Stem Cell 2010, 8:31-45.

50. Darabi R, Santos FN, Filareto A, Pan W, Koene R, Rudnicki MA, Kyba M, Perlingeiro RC: Assessment of the myogenic stem cell compartment following transplantation of Pax3/Pax7-induced embryonic stem cell- derived progenitors. Stem Cells 2011, 29:777-790.

51. Fukuda T, Ahearn M, Roberts A, Mattaliano RJ, Zaal K, Ralston E, Plotz PH, Raben N: Autophagy and mistargeting of therapeutic enzyme in skeletal muscle in Pompe disease. Mol Ther 2006, 14:831-839.

52. Raben N, Schreiner C, Baum R, Takikita S, Xu S, Xie T, Myerowitz R, Komatsu M, Van der Meulen JH, Nagaraju K, Ralston E, Plotz PH: Suppression of autophagy permits successful enzyme replacement therapy in a lysosomal storage disorder--murine Pompe disease. Autophagy 2010, 6:1078-1089.

53. Parenti G: Treating lysosomal storage diseases with pharmacological chaperones: from concept to clinics. EMBO Mol Med 2009, 1:268-279.

54. Fan JQ, Ishii S, Asano N, Suzuki Y: Accelerated transport and maturation of lysosomal alpha-galactosidase A in Fabry lymphoblasts by an enzyme inhibitor. Nat Med 1999, 5:112-115.

55. Maegawa GH, Tropak M, Buttner J, Stockley T, Kok F, Clarke JT, Mahuran DJ: Pyrimethamine as a potential pharmacological chaperone for late-onset forms of GM2 gangliosidosis. J Biol Chem 2007, 282:9150-9161.

56. Flanagan JJ, Rossi B, Tang K, Wu X, Mascioli K, Donaudy F, Tuzzi MR, Fontana F, Cubellis MV, Porto C, Benjamin E, Lockhart DJ, Valenzano KJ, Andria G,Parenti G, Do HV: The pharmacological chaperone 1-deoxynojirimycin increases the activity and lysosomal trafficking of multiple mutant forms of acid alpha-glucosidase. Hum Mutat 2009, 30:1683-1692.

57. Hamuro Y, Coales SJ, Southern MR, Nemeth-Cawley JF, Stranz DD, Griffin PR: Rapid analysis of protein structure and dynamics by hydrogen/deuterium exchange mass spectrometry. J Biomol Tech 2003, 14:171-182.

58. Zanella F, Lorens JB, Link W: High content screening: seeing is believing. Trends Biotechnol 2010, 28:237-245.

59. MuTW, Fowler DM, Kelly JW: Partial restoration of mutant enzyme homeostasis in three distinct lysosomal storage disease cell lines by altering calcium homeostasis. PLOS Biol 2008, 6:e26.

60. Wang F, Chou A, Segatori L: Lacidipine remodels protein folding and Ca 2+ homeostasis in Gaucher's disease fibroblasts: a mechanism to rescue mutant glucocerebrosidase. Chem Biol 2011, 18:766-776.

61. Mu TW, Ong DS, Wang YJ, Balch WE, Yates JR 3rd, Segatori L, Kelly JW: Chemical and biological approaches synergize to ameliorate proteinfolding diseases. Cell 2008, 134:769-781.

62. Hartl FU, Bracher A, Hayer-Hartl M: Molecular chaperones in protein folding and proteostasis. Nature 2011, 475:324-332.

63. Koul D, Shen R, Kim YW, Kondo Y, Lu Y, Bankson J, Ronen SM, Kirkpatrick DL, Powis G, Yung WK: Cellular and in vivo activity of a novel PI3K inhibitor, PX-866, against human glioblastoma. Neuro Oncol 2010, 12:559-569.

64. Zammit VA, Ramsay RR, Bonomini M, Arduini A: Carnitine, mitochondrial function and therapy. Adv Drug Deliv Rev 2009, 61:1353-1362.

65. Su LJ, Auluck PK, Outeiro TF, Yeger-Lotem E, Kritzer JA, Tardiff DF, Strathearn KE, Liu F, Cao S, Hamamichi S, Hill KJ, Caldwell KA, Bell GW, Fraenkel E,Cooper AA, Caldwell GA, McCaffery JM, Rochet JC, Lindquist S: Compounds from an unbiased chemical screen reverse both ER-to-Golgi trafficking defects and mitochondrial dysfunction in Parkinson's disease models. Dis Model Mech 2010, 3:194-208.

66. Desbordes SC, Placantonakis DG, Ciro A, Socci ND, Lee G, Djaballah H, Studer L: High-throughput screening assay for the identification of compounds regulating self-renewal and differentiation in human embryonic stem cells. Cell Stem Cell 2008, 2:602-612

67. Friedrichs S, Malan D, Matuscheck Y, Fleischmann BK, Sasse P: Highthroughtput screening of induced pluripotent stem cell-derived cardiomyocytes with long QT-syndrome 3. Acta Physiologica 2012, 204 (Suppl 689):189.

68. Huang SG: Development of a high throughput screening assay for mitochondrial membrane potential in living cells. J Biomol Screen 2002, 7:383-389.

69. Li M, Chen X, Ye QZ, Vogt A, Yin XM: A high-throughput FRET-based assay for determination of Atg4 activity. Autophagy 2012, 8

70. Watanabe K, Ueno M, Kamiya D, Nishiyama A, Matsumura M, Wataya T, Takahashi JB, Nishikawa S, Muguruma K, Sasai Y: A ROCK inhibitor permits survival of dissociated human embryonic stem cells. Nat Biotechnol 2007, 25:681-686.

71. Bajpai R, Lesperance J, Kim M, Terskikh AV: Efficient propagation of single cells Accutase-dissociated human embryonic stem cells. Mol Reprod Dev 2008, 75:818-827.

72. Ebert $A D$, Svendsen $C N$ : Human stem cells and drug screening: opportunities and challenges. Nat Rev Drug Discov 2010, 9:367-372. 
73. Ebert AD, Liang P, Wu JC: Induced pluripotent stem cells as a disease modeling and drug screening platform. J Cardiovasc Pharmacol 2012, Jan 11. [Epub ahead of print].

74. Wang P, Rodriguez RT, Wang J, Ghodasara A, Kim SK: Targeting SOX17 in human embryonic stem cells creates unique strategies for isolating and analyzing developing endoderm. Cell Stem Cell 2011, 8:335-346.

75. Vierbuchen T, Ostermeier A, Pang ZP, Kokubu Y, Sudhof TC, Wernig M: Direct conversion of fibroblasts to functional neurons by defined factors. Nature 2010, 463:1035-1041.

76. Pfisterer U, Kirkeby A, Torper O, Wood J, Nelander J, Dufour A, Bjorklund A, Lindvall O, Jakobsson J, Parmar M: Direct conversion of human fibroblasts to dopaminergic neurons. Proc Natl Acad Sci U S A 2011, 108:10343-10348.
77. Schule B, Pera RA, Langston JW: Can cellular models revolutionize drug discovery in Parkinson's disease? Biochim Biophys Acta 2009, 1792:1043-1051.

78. Lengerke C, Daley GQ: Disease models from pluripotent stem cells. Ann N Y Acad Sci 2009, 1176:191-196.

doi: $10.1186 /$ scrt125

Cite this article as: Huang H-P, et al.: Induced pluripotent stem cell technology for disease modeling and drug screening with emphasis on lysosomal storage diseases. Stem Cell Research \& Therapy 2012, 3:34. 